\title{
Diel habitat-use patterns of commercially important fishes in a marine protected area in the Philippines
}

\author{
Kentaro Honda ${ }^{1,4, *}$, Wilfredo H. $\mathrm{Uy}^{2}$, Darwin I. Baslot ${ }^{2}$, Allyn Duvin S. Pantallano ${ }^{2}$, \\ Yohei Nakamura ${ }^{3}$, Masahiro Nakaoka ${ }^{1}$ \\ ${ }^{1}$ Akkeshi Marine Station, Field Science Center for Northern Biosphere, Hokkaido University, Aikappu, Akkeshi, \\ Hokkaido 088-1114, Japan \\ ${ }^{2}$ Institute of Fisheries Research and Development, Mindanao State University at Naawan, 9023 Naawan, Misamis Oriental, \\ the Philippines \\ ${ }^{3}$ Graduate School of Kuroshio Science, Kochi University, 200 Monobe, Nankoku, Kochi 783-8502, Japan \\ ${ }^{4}$ Present address: Hokkaido National Fisheries Research Institute, Fisheries Research Agency, 2-2 Nakanoshima, \\ Toyohira-ku, Sapporo, Hokkaido 062-0922, Japan
}

\begin{abstract}
The diel habitat-use patterns of commercially important fishes in a small marine protected area (MPA) $\left(0.31 \mathrm{~km}^{2}\right)$ containing coral reef and seagrass habitats were examined by passive acoustic telemetry during 2011 and 2012. The occurrence patterns of the target fishes both inside and outside the MPA were also observed. Thirty individuals from 6 species $(20.2$ to $41.4 \mathrm{~cm}$ fork length) were caught, acoustically tagged and released inside the MPA, and 4 to $210 \mathrm{~d}$ of tracking data were then obtained from 28 detected fishes. Lutjanus monostigma, Lethrinus atkinsoni, and Lethrinus obsoletus were found to mostly inhabit the coral reef. The remaining 3 species (Lutjanus argentimaculatus, Lethrinus harak, and Siganus guttatus) utilized both coral and seagrass habitats but showed different patterns: Lutjanus argentimaculatus visited seagrass only at night; Lethrinus harak occurred in the coral reef more at night than in the day, showing the opposite pattern in seagrass; and S. guttatus exhibited the converse pattern to L. harak. More than one-third of the tracked individuals moved inside and outside the MPA more than once per day on average during the tracking period. However, 95.4\% of detections were recorded by acoustic receivers deployed inside the MPA. Underwater visual surveys revealed that the densities of some target fishes were significantly higher inside than outside the MPA. These findings suggest that the MPA protects the core of fish home ranges.
\end{abstract}

KEY WORDS: Acoustic telemetry - Habitat connectivity - Marine protected area $\cdot$ Coral reef · Seagrass bed $\cdot$ Commercially important fishes

\section{INTRODUCTION}

The conservation of tropical marine resources is becoming increasingly important with the growing human population and the associated decline in food resources (Newton et al. 2007, Mora et al. 2011). Marine protected areas (MPAs) are a common fisheries management tool in the tropics (see review by Russ 2002). The area of MPAs worldwide increased at an annual rate of $4.6 \%$ during 1984 to 2006, and the total

*Corresponding author: fbmods@affrc.go.jp area of the sea surface covered by MPAs had reached 4.21 million $\mathrm{km}^{2}(1.17 \%)$ by 2010 (Spalding et al. 2010). Since the 1980s, scientists have been investigating the effectiveness of marine reserves in protecting fisheries. The evidence shows that some reserves have increased the density and biomass of commercially important fish species on reefs, and that the adult fish biomass moves to areas adjacent to reserves via density-dependent movements known as spillover effects (Russ \& Alcala 1996, 2003, Halpern 2003). 
Although MPAs provide a number of benefits, such as protecting target stocks and spillover to adjacent areas, their positive effects are sometimes limited (Mora et al. 2011, Edgar et al. 2014), largely because of illegal fishing inside MPAs (e.g. Tobey \& Torell 2006, Christie et al. 2009) and inappropriate MPA designs. Such designs result from a lack of biological and ecological information on various factors such as dispersal abilities, habitat-use patterns, and the home ranges of target organisms (e.g. Grober-Dunsmore et al. 2007, Planes et al. 2009, Alós et al. 2011). As populations inside reserves can be influenced by the movements of individuals, information on the spatial scales of adult movement and propagule dispersal is critical for the design of effective MPAs (Mora et al. 2006, Grüss et al. 2011, Pittman et al. 2014).

Halpern \& Warner (2003) and Shanks et al. (2003) suggested areas of 10 to $100 \mathrm{~km}^{2}$ and 12.6 to $28.3 \mathrm{~km}^{2}$, respectively, as preferable sizes for MPAs, taking into account the dispersal distances of benthic marine organism propagules (e.g. algae, mollusks, crustaceans, and fishes). Generally, the home ranges of large herbivorous and predatory fishes cover several km² (Palumbi 2004, Sale et al. 2005, Pittman et al. 2014). Chateau \& Wantiez (2009) used acoustic telemetry to study the movement patterns of 4 commercially important reef fish species among 3 reefs, one within an MPA $\left(8.5 \mathrm{~km}^{2}\right)$ and the other 2 outside the MPA. They reported that $20 \%$ of individuals visited reefs other than the one onto which they had been released, and pointed out that the effectiveness of the MPA was limited because of the wide migration ranges of the tracked fishes. Meyer et al. (2010) used acoustic telemetry to track 70 adult scarine, acanthurid, and mullid fishes for 1 to $612 \mathrm{~d}$ (median, $52 \mathrm{~d}$ ) near an MPA containing a fringing reef in Kaelakekua Bay, Hawaii. They suggested that a $1.3 \mathrm{~km}^{2}$ MPA was suitable for most of the tracked fish species because more than $90 \%$ of them did not move frequently out of the MPA. Thus, the best size for MPAs can differ widely depending on the target species and location.

The Philippines contains the highest fish biodiversity in the world. Thus, it is widely recognized as a global priority for marine conservation (Spalding et al. 2001, Carpenter \& Springer 2005). The contribution of reef fish to the total fisheries catch of the Philippines ranged from $8 \%$ to $20 \%$ (143200 to 358000 t) in the early 1980s, but now most reef areas have been overexploited or destroyed by humanrelated activities (e.g. Primavera 1995, White et al. 2000, Unsworth \& Cullen 2010). Although nearly
1000 MPAs have been established in the Philippines, only limited areas (ca. $10 \%$ ) of them are designated as no-take MPAs (Weeks et al. 2010) and most of them have difficulty due to insufficient management support (White et al. 2006). At least 2 major concerns have been voiced for Philippine MPAs. First, most Philippine no-take MPAs are relatively small. Approximately $90 \%$ of Philippine MPAs have a total area of less than $1 \mathrm{~km}^{2}$, and the most common size class is 0.1 to $0.5 \mathrm{~km}^{2}$ (Weeks et al. 2010). Therefore, most are too small to cover the home ranges of the species targeted by fisheries. Second, most Philippine MPAs are focused on coral reefs, and relatively few include seagrass and/or mangrove habitats (MPA Support Network 2014). Commercially important reef fishes in the Philippines, such as those in the Lutjanidae, Lethrinidae, and Siganidae families, often use adjacent back-reef seagrass beds and mangrove areas as nursery and/or feeding grounds (Shibuno et al. 2008, Unsworth et al. 2009, Honda et al. 2013). If back-reef seagrass and mangrove habitats are routinely used by commercially important fishes during their juvenile and adult stages, these habitats must be included in MPAs to sustain fishery yields. Although some fisheries scientists, managers, and conservationists acknowledge these possible defects in current MPA design (Olds et al. 2012, Nagelkerken et al. 2013), supporting data are limited for the Philippines and also for other areas (Luo et al. 2009, Olds et al. 2013).

The habitat-use patterns of large mobile fishes are generally difficult to understand because they have wide home ranges and diel movement patterns (Pittman et al. 2014). Underwater visual censuses have been used to assess fish movements across multiple habitats (e.g. Nagelkerken et al. 2000a, Unsworth et al. 2007, Honda et al. 2013) or MPA boundaries (e.g. Russ \& Alcala 1996, Zeller et al. 2003). Underwater visual surveys can provide quantitative data, although the obtained data are sometimes instantaneous (MacNeil et al. 2008), and there are practical difficulties during the night (Nagelkerken et al. 2000b). Biotelemetry surveys can track the movements of individuals in detail, but sample numbers are small in most cases (e.g. Hussey et al. 2015, Matley et al. 2015). Therefore, a combination of both methods may enable us to gain a more profound understanding of the home ranges, movements, and habitat-use patterns of the target species.

The aim of this study was to assess the movements and occurrences of commercially important species (members of the Lutjanidae, Lethrinidae, and Siganidae families) within multiple habitats inside and outside of an MPA, and to evaluate the importance of 
this information for designing effective MPAs. We used passive acoustic telemetry to examine the movement and diel habitat-use patterns of 6 fish species in a small MPA $\left(0.31 \mathrm{~km}^{2}\right)$ that included both coral reef and seagrass bed habitats. A visual transect survey was also conducted to assess fish daytime abundance in the habitats inside and outside the MPA.

\section{MATERIALS AND METHODS}

\section{Study site and acoustic receiver array}

The field study was conducted from February 2011 to August 2012 on a fringing reef with a reef flat zone facing the open sea off Laguindingan, northern Mindanao Island, the Philippines (Fig. 1). A no-take MPA with a total area of $0.31 \mathrm{~km}^{2}$ (length from shore side to offshore side: ca. $760 \mathrm{~m}$, width: 360 to $450 \mathrm{~m}$ ) was established here in 2002. The seascape composition of the MPA includes a near-shore mangrove area, a seagrass bed, and a fringing coral reef. The coral reef comprises hermatypic corals, such as tabular and branching Acropora (living coral coverage > 80\%). The seagrass bed is dominated by Thalassia hemprichii $(63.6 \%$ of cover) and Enhalus acoroides (4.3\%) (Honda et al. 2013). The mangroves at the site are dominated by Rhizophora apiculata. The mangroves protect the coastal communities from strong winds. The offshore edge of the MPA consists of a steep reef wall (i.e. drop-off), with a bottom depth along the wall between 20 and $30 \mathrm{~m}$. The horizontal distance between the shallowest and deepest parts along the wall is generally less than $5 \mathrm{~m}$. This MPA has been strictly regulated since its establishment in 2002 through the installation of a watchtower. Hook-and-line and gillnet fishing activities operate legally and regularly along the boundaries of the MPA (authors' pers. obs.). This site was selected not only because it contains multiple habitats, but also because the no-take is strictly regulated and its size is typical of MPAs in the Philippines.

Four acoustic receivers (VR2W, Vemco) were deployed near the edge of the coral reef (2 outside [Stns C1 and C4] and 2 inside the MPA [Stns C2 and C3]) and 5 receivers were deployed on the seagrass bed (2 outside [Stns S1 and S5] and 3 inside the MPA [Stns S2 to S4]) (Fig. 1). The receivers were located at depths which fluctuated depending on the tide (ca. 4 to $10 \mathrm{~m}$ on the reef and ca.
0.5 to $2.0 \mathrm{~m}$ in the seagrass). At the coral stations, the receivers were anchored using aluminum cable locked to coral or rocks and attached to 2 buoys. The bottom of each receiver was $1.5 \mathrm{~m}$ away from the locked point. At the seagrass stations, the receivers were tethered to a concrete anchor with a rope, which was attached to a buoy. The bottom of each receiver was $20 \mathrm{~cm}$ away from the anchor. All receivers were deployed continuously from 19 February 2011 to 24 August 2012, except for between 17 and 28 May 2011 and between 25 December 2011 and 7 May 2012. The latter exception was because expected battery lives of most transmitters used in this study were within 2 mo (see following section) after 7 May 2012.

The detection ranges of the receivers were assumed to fluctuate depending on the bottom topography and sea conditions, such as depth, tide, wave action, and wind speed (Simpfendorfer et al. 2008, Welsh \& Bellwood 2012, Farmer et al. 2013, Kessel et al. 2014). Based on the results of a preliminary experiment and real-time detection, the detection ranges of the receivers were in a radius from 50 to $150 \mathrm{~m}$ at the coral reef stations and from 30 to $80 \mathrm{~m}$ at the seagrass stations (Fig. 1). The difference in the detection ranges between habitats may have resulted from differences in bottom depth (Welsh et al. 2012). As shown in Fig. 1, our study area was not fully covered by the ranges of the arrayed receivers, and so not all presences and movements of tagged fishes were recorded.
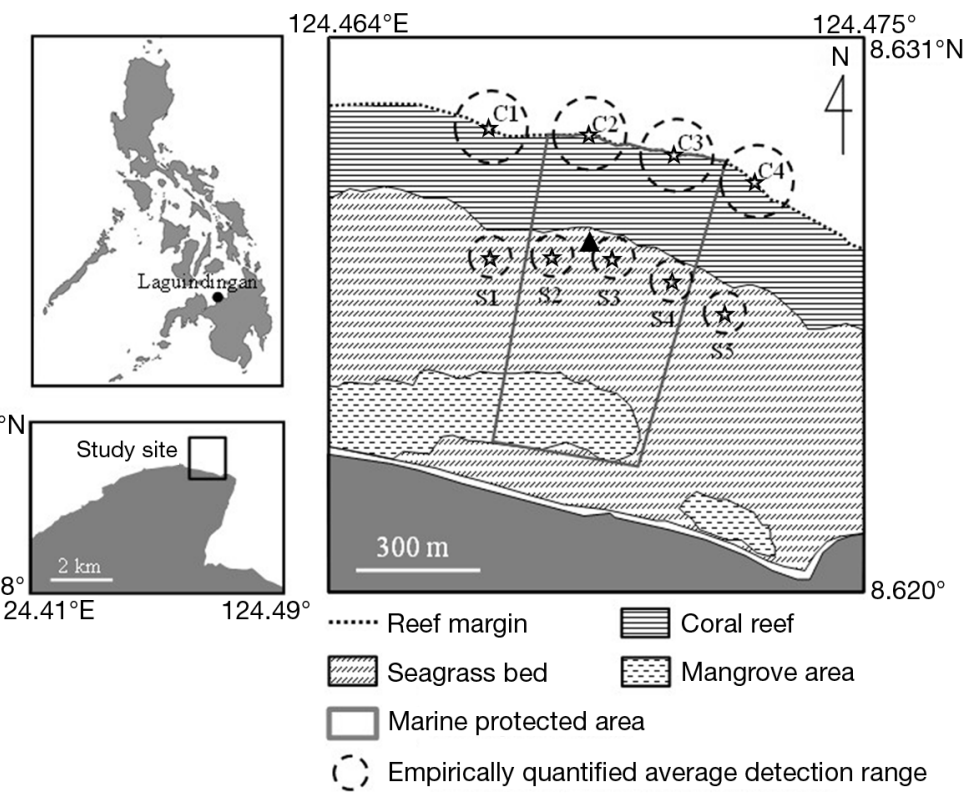

Fig. 1. Geographic location of the study site off Laguindingan, northern Mindanao Island, Philippines. is: receiver deployment stations;

$\boldsymbol{\Delta}$ : watchtower 


\section{Fish capture and tagging for acoustic telemetry}

The target species were Lutjanus argentimaculatus, Lutjanus monostigma (Lutjanidae), Lethrinus harak, Lethrinus atkinsoni, Lethrinus obsoletus (Lethrinidae), and Siganus guttatus (Siganidae). These species are listed as 'commercial fish' in FishBase (Froese \& Pauly 2015) and are regarded as common fishery targets at our study site (authors' pers. obs.).

All experimental fishes were collected inside and along the offshore outer edge of the MPA using several types of local fishing gear. Hook-and-line, longlines, and box-shaped fish traps, known locally as bubo, were used. All fish traps were located at the bottom of the reef wall at depths of 25 to $30 \mathrm{~m}$, and were retrieved after 3 to $14 \mathrm{~d}$ of deployment. Traps containing fish were not recovered immediately but were transferred to shallower depths for 2 to $3 \mathrm{~d}$ to allow the fish to decompress. The individuals captured using these fishing methods were 4 Lutjanus argentimaculatus (22.6 to $40.9 \mathrm{~cm}$ fork length [FL]), 7 L. monostigma (22.4 to $41.4 \mathrm{~cm} \mathrm{FL),} 6$ Lethrinus harak (20.2 to $25.9 \mathrm{~cm} \mathrm{FL),} 5$ L. atkinsoni (20.8 to $24.6 \mathrm{~cm}$ FL), 2 L. obsoletus (21.9 to $23.4 \mathrm{~cm} \mathrm{FL),} \mathrm{and} 6 \mathrm{~S}$. guttatus (23.1 to $25.3 \mathrm{~cm}$ FL) (Table 1). Individual fishes were given identifiers based on their abbreviated species name and replicate number (see Table 1). Captured fishes were placed immediately in an aerated tub on the boat before being transferred to a fish cage (ca. $1.5 \times 1.5 \times 1.5 \mathrm{~m}$ ) installed near the watchtower (Fig. 1). The fish-tagging operation started $1 \mathrm{~h}$ after the fishes were caged, to allow them time to recover from the stress of being caught.

Target fishes were transferred to a tank before tagging and were treated with an anesthetic mixture of $0.012 \%$ ougenol and seawater. After immobilization, a latex-covered acoustic transmitter (V9-2H or V13$1 \mathrm{~L}$, Vemco) was implanted surgically into the abdominal cavity. The V9-2H transmitter was $9 \mathrm{~mm}$ in diameter and $29 \mathrm{~mm}$ in length, and weighed $4.7 \mathrm{~g}$. The V13-1L transmitter was $13 \mathrm{~mm}$ in diameter and $36 \mathrm{~mm}$ in length, and weighed $11 \mathrm{~g}$. The expected battery lives were 53 and $339 \mathrm{~d}$ for the V9 and V13 transmitters, respectively. The frequency of both transmitter types was $69 \mathrm{kHz}$, and both randomly transmitted a set of 6 pulses once every 20 (minimum) to 40 (maximum) s. After the transmitter was implanted, the incision of each fish was sutured with biodegradable silk, and an antibiotic ointment was applied to the incision. Each fish was measured before it was placed back in the cage. The proportion of transmitter weight to fish body weight was 0.9 to
$3.6 \%$ (Table 1). After about $30 \mathrm{~min}$, all fishes were confirmed to have recovered from the tagging operation and were released near the watchtower at depths of 1 to $2 \mathrm{~m}$ (Fig. 1). Two S. guttatus (Si-gu1 and 2) were released at the coral reef inside the MPA because of the very low tide conditions in the seagrass bed at the time of release.

Preliminary experiments with dummy tags were conducted to confirm the efficiency of tagging and all the experimental fishes survived and showed no strange behavior during the captive period.

\section{Data analyses}

Detection data obtained within $1 \mathrm{~d}$ after release were excluded from analyses to account for the negative effect of tagging stress. Abnormal data (i.e. cases where 1 fish was detected by multiple receivers simultaneously or shuttled between adjacent stations or between coral [inside] and seagrass [outside] stations within $5 \mathrm{~min}$ ) were also excluded from the analyses. The individual residence index (Alós et al. 2011), defined as the ratio of the number of days detected to the length of the period between Day 1 after release and the last detection date (tracking period), was calculated to determine how frequently a fish was certainly present in the fixed array (Collins et al. 2007). All detection data were divided into the following 4 habitat types based on station location: coral reef outside the MPA (i.e. Stns C1 and C4); coral reef inside the MPA (Stns C2 and C3); seagrass bed inside the MPA (Stns S2 to S4); and seagrass bed outside the MPA (S1 and S5) (Fig. 1). Although the detection ranges at coral stations included the offshore area of the reef edge (i.e. outside the MPA), fishes detected at those stations were regarded as having remained along the reef edge or within the reef flat, because all the target species were reefassociated fishes.

The number of fish movements between the coral and seagrass habitats and between the inside and outside of the MPA, and their corresponding daily mean values, were estimated based on detections in each habitat type and were used to determine the movement patterns of each tracked individual. A last detection at 1 station before being detected at another station in a different habitat type was counted as 1 movement. Here, data obtained on the first days of tracking (because $24 \mathrm{~h}$ of data was unavailable) and on days with no detection (no information on where fishes were located) were excluded from analyses. The estimated number of fish move- 


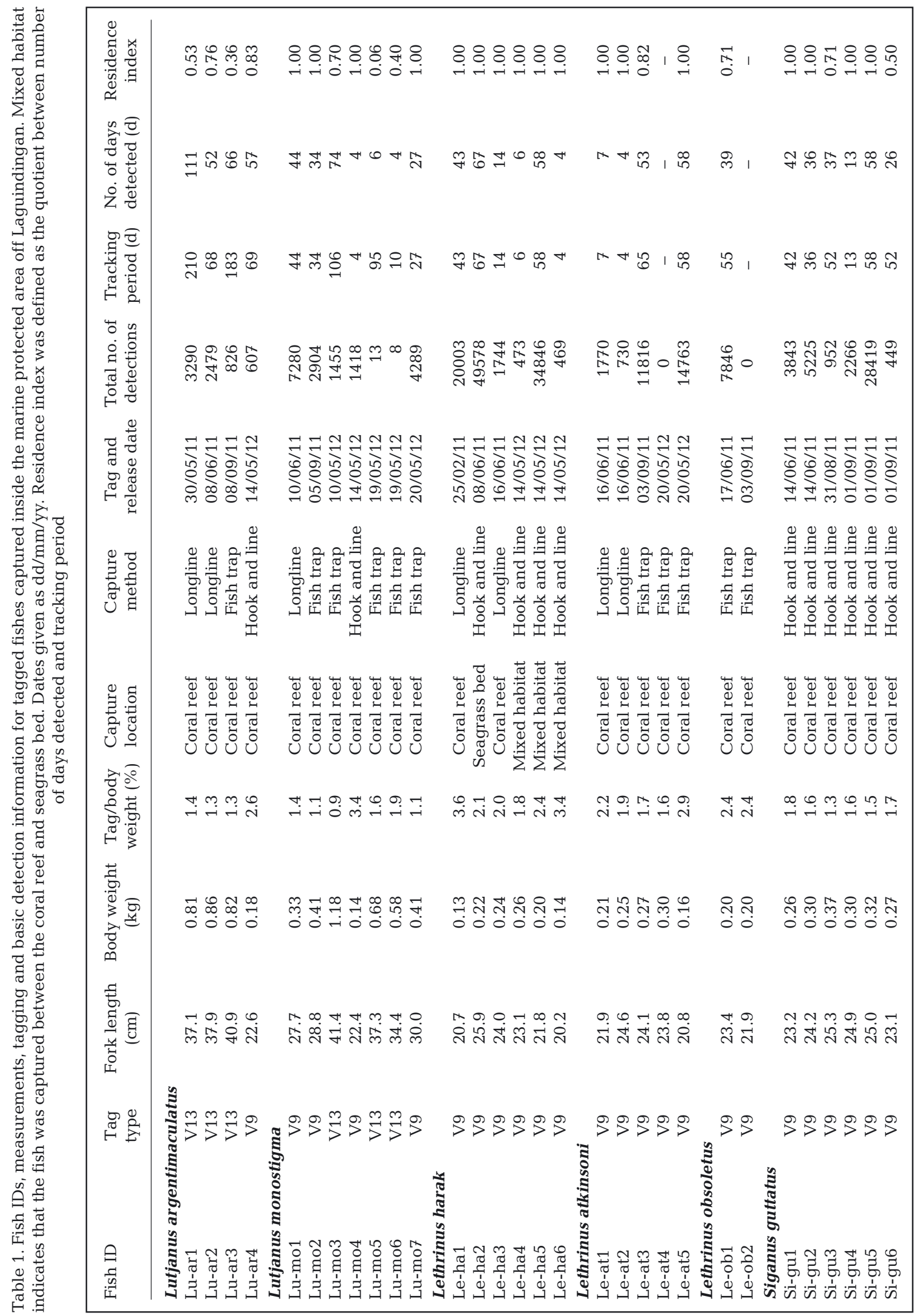


ments was defined as the 'least' number, considering that the study area was not fully covered by the detection ranges of the receivers.

To reveal fish diel habitat-use patterns, the mean number of hours spent per day in the coral and seagrass habitats were determined for each fish. Each day was divided into $24 \mathrm{~h}$, and hourly presence (1 or more detections: 1) or absence (no detection: 0) of each tracked fish at each habitat during the day and night was counted. Corresponding mean daily values were estimated. The 2 hours that included sunrise and sunset at Laguindingan (Morrissey 2015) on each day were excluded. The obtained daytime and nighttime values were standardized based on the total number of daytime and nighttime hours during the tracking periods. The number of hours present in each habitat was used to reduce the hourly bias in detection frequency that differs significantly among time periods (Payne et al. 2010, Koeck et al. 2013). In this analysis, data from fishes tracked for longer than $10 \mathrm{~d}$ and recorded in both the coral and seagrass habitats for more than $5 \mathrm{~d}$ were used. Data from the first tracking days and from the no-detection days were excluded from the analysis for the reasons noted above. The Wilcoxon signed-rank test was used to detect differences in the number of hours present per day between the coral and seagrass habitats for each time period, and between the time periods in each habitat.

\section{Fish visual census}

The fish visual censuses (FVCs) targeted only the 6 species noted above. The FVCs were conducted 6 times (March, June, and September 2011, and March, May, and September 2012) at 2 stations inside the MPA (between Stns C2 and C3, and S3) and 4 stations outside the MPA (Stns C1, C4, S1, and S5). Ten $1 \times 20 \mathrm{~m}\left(20 \mathrm{~m}^{2}\right)$ belt transects were established haphazardly using a scaled rope within a $50 \mathrm{~m}$ radius of each station (see Unsworth et al. 2008, Honda et al. 2013). Only 7 transects were surveyed in the coral reef inside the MPA in September 2011. The transects were separated by at least $5 \mathrm{~m}$. The number of individuals of the target species was counted in each transect, and their sizes (total length, TL) were recorded underwater using a ruler attached to a recording slate. Only fishes larger than $20 \mathrm{~cm}$ TL were targeted, because the main objective of the FVCs was to complement the telemetry results. All FVCs were conducted during the day between 08:00 and 16:00 $\mathrm{h}$, using SCUBA in the coral reef at water depths of 5 to $8 \mathrm{~m}$ and snorkeling in the seagrass bed at depths of 1.0 to $1.5 \mathrm{~m}$. Data from all of the transects in each of the 4 habitat types were pooled, and the mean number of individuals of each species per $1000 \mathrm{~m}^{2}$ was compared between sites inside and outside the MPA in each habitat, and between habitats within the MPA. Data were compared using the Wilcoxon rank sum test. All the statistical analyses were conducted using $\mathrm{R}$ version 3.2.0 (R Core Team 2015).

\section{RESULTS}

\section{Acoustic telemetry}

A total of 209761 detections originating from 28 of the 30 tagged fishes were recorded during the study (Table 1). Although tracking periods varied among individuals, 19 individual fishes of the 6 fish species (67.9\% of all tracked fishes) were tracked for longer than 1 mo (Table 1). Five fishes (17.9\%) were tracked for fewer than $10 \mathrm{~d}$. The residence indices of 11 individuals $(50 \%)$ of 5 species (other than Lethrinus harak) were less than 1 ; in particular, those of Lutjanus argentimaculatus were all less than 0.9 (Table 1).

\section{Habitat-use patterns in coral reef and seagrass bed}

Two types of habitat-use patterns were observed; single or multiple habitat use. Most detections (>99\% of detections) of Lutjanus monostigma, Lethrinus atkinsoni, and Lethrinus obsoletus were on the coral reef, except for Lu-mo4 (59.7\%) (Figs. 2 \& 3). In contrast, Lutjanus argentimaculatus, Lethrinus harak, and Siganus guttatus were detected in both the coral reef and seagrass bed. Intraspecific variations in habitat-use patterns within a similar size class (37.1 to $40.9 \mathrm{~cm}$ FL for Lutjanus argentimaculatus, 20.2 to $25.9 \mathrm{~cm}$ FL for Lethrinus harak and 23.1 to $25.3 \mathrm{~cm}$ FL for $S$. guttatus) were observed between the 2 habitats for Lutjanus argentimaculatus, Lethrinus harak, and $S$. guttatus (Fig. 3). Some individuals were largely restricted $(>95 \%)$ to the coral reef (Lu-ar1 and 3 and Si-gu3 and 6) or to the seagrass (Le-ha4 and 6), but others were not. The 2 lutjanid species also showed size-specific variations in habitat-use patterns. Compared with larger fishes, the smaller fishes of Lutjanus argentimaculatus (Lu-ar4, $22.6 \mathrm{~cm}$ FL) and L. monostigma (Lu-mo4, $22.4 \mathrm{~cm} \mathrm{FL)} \mathrm{were}$ more often detected in the seagrass bed $199.5 \%$ for Lu-ar4 and $40.3 \%$ for Lu-mo4, although Lu-mo4 was 

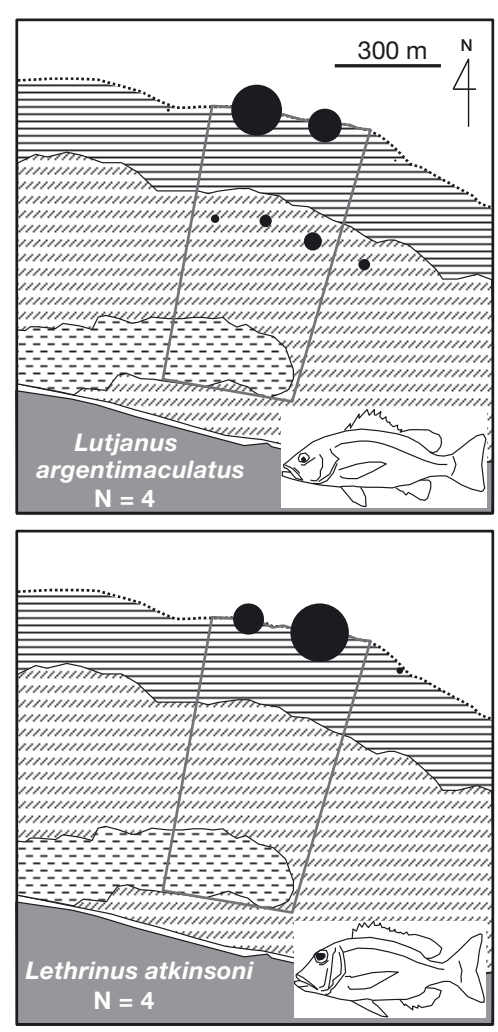
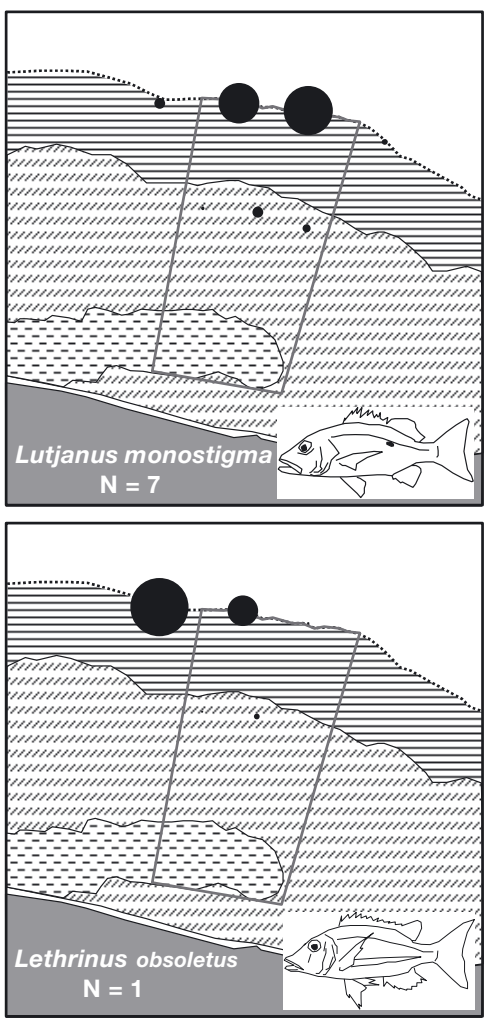

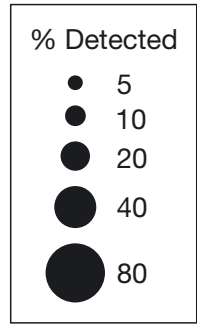

Fig. 2. Spatial distribution of detections of each species

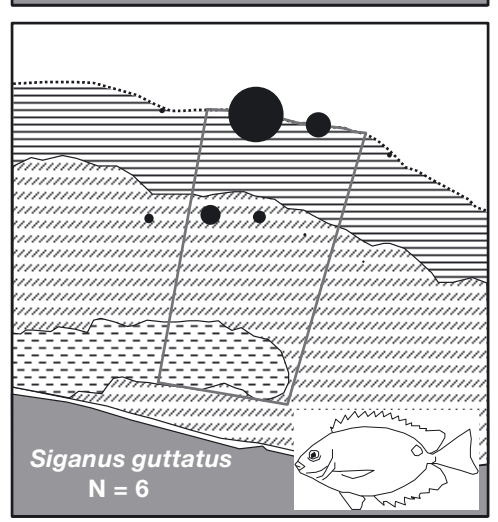

...... Reef margin

Coral reef

एim Seagrass

bed

$E-G$ Mangrove

area

Marine protected area

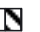

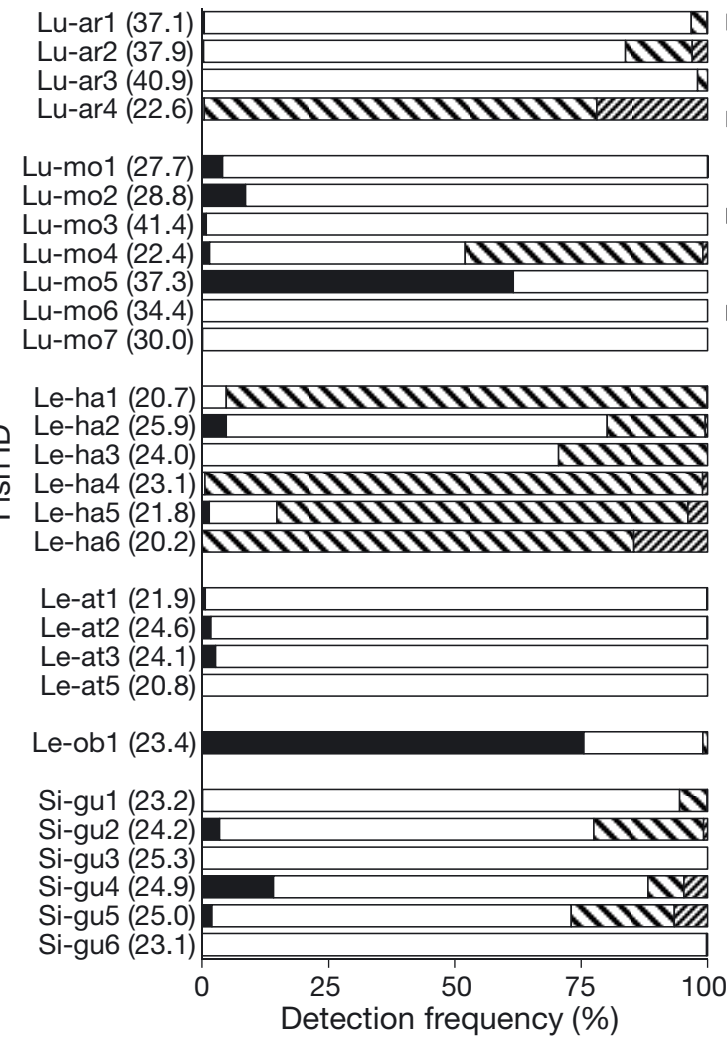

Coral reef outside the MPA (C1 \& C4)

$\square$ Coral reef inside the MPA (C2-C3)

$\nabla$ Seagrass bed inside the MPA (S2-S4)

Seagrass bed outside the MPA (S1 \& S5)

Fig. 3. Detection frequency in each habitat type used by each tracked fish during the study period. $\mathrm{C} 1$ to $\mathrm{C} 4$ and S1 to S5 indicate station locations (see Fig. 1). Refer to Table 1 for definitions of fish ID. Numbers in parentheses indicate fork length $(\mathrm{cm})$ only recorded on 4 d) (Fig. 3). Results of the mean daily least number of cross-habitat movements showed that two-thirds of Lethrinus harak and S. guttatus moved more than once between the coral and seagrass habitats, whereas all tracked Lutjanus argentimaculatus moved less frequently (less than once per day) (Fig. 4a).

Diel coral and seagrass habitatuse patterns were observed for 3 Lutjanus argentimaculatus, 4 Lethrinus harak, and 4 S. guttatus individuals, and the patterns differed among species (Fig. 5). All 3 Lutjanus argentimaculatus individuals were detected on the coral reef during the day and night, but in the seagrass bed only at night (Fig. 5). Lethrinus harak individuals occurred on the coral reef more during the night than during the day (Wilcoxon signed-rank test, $\mathrm{p}<0.05$ for all individuals), while 


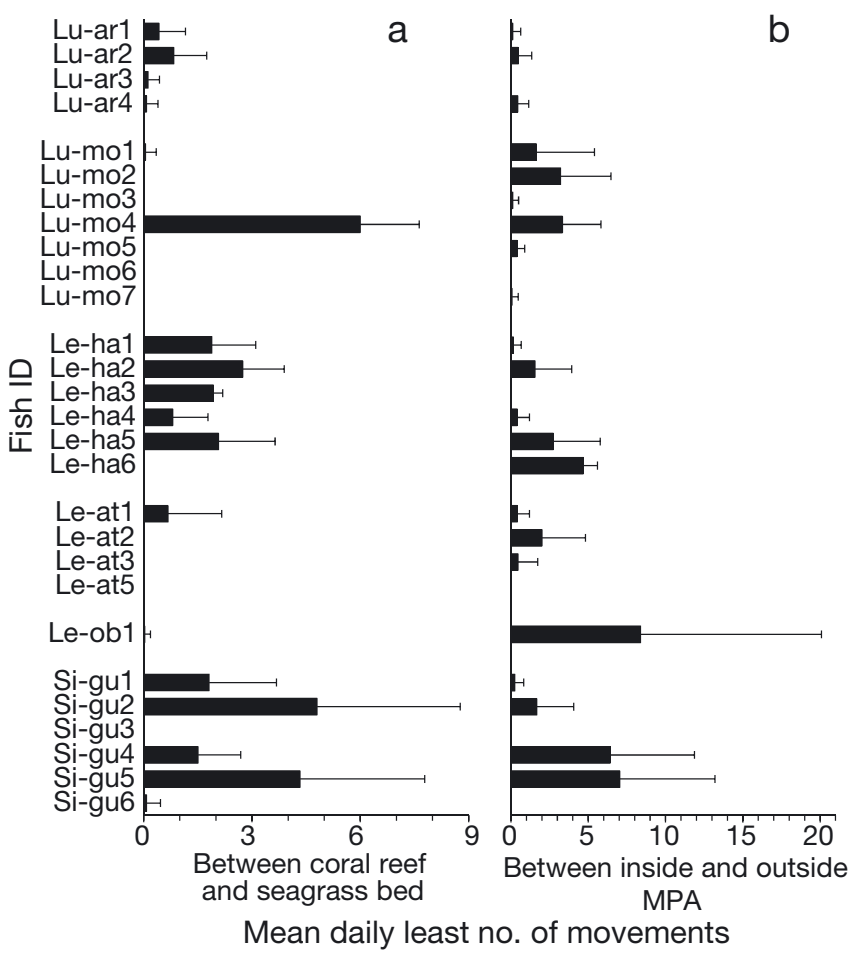

Fig. 4. Mean daily least number of movements (+SD) recorded by each tracked fish (a) between coral reef and seagrass bed, and (b) between inside and outside the marine protected area (MPA). Refer to Table 1 for definitions of fish ID
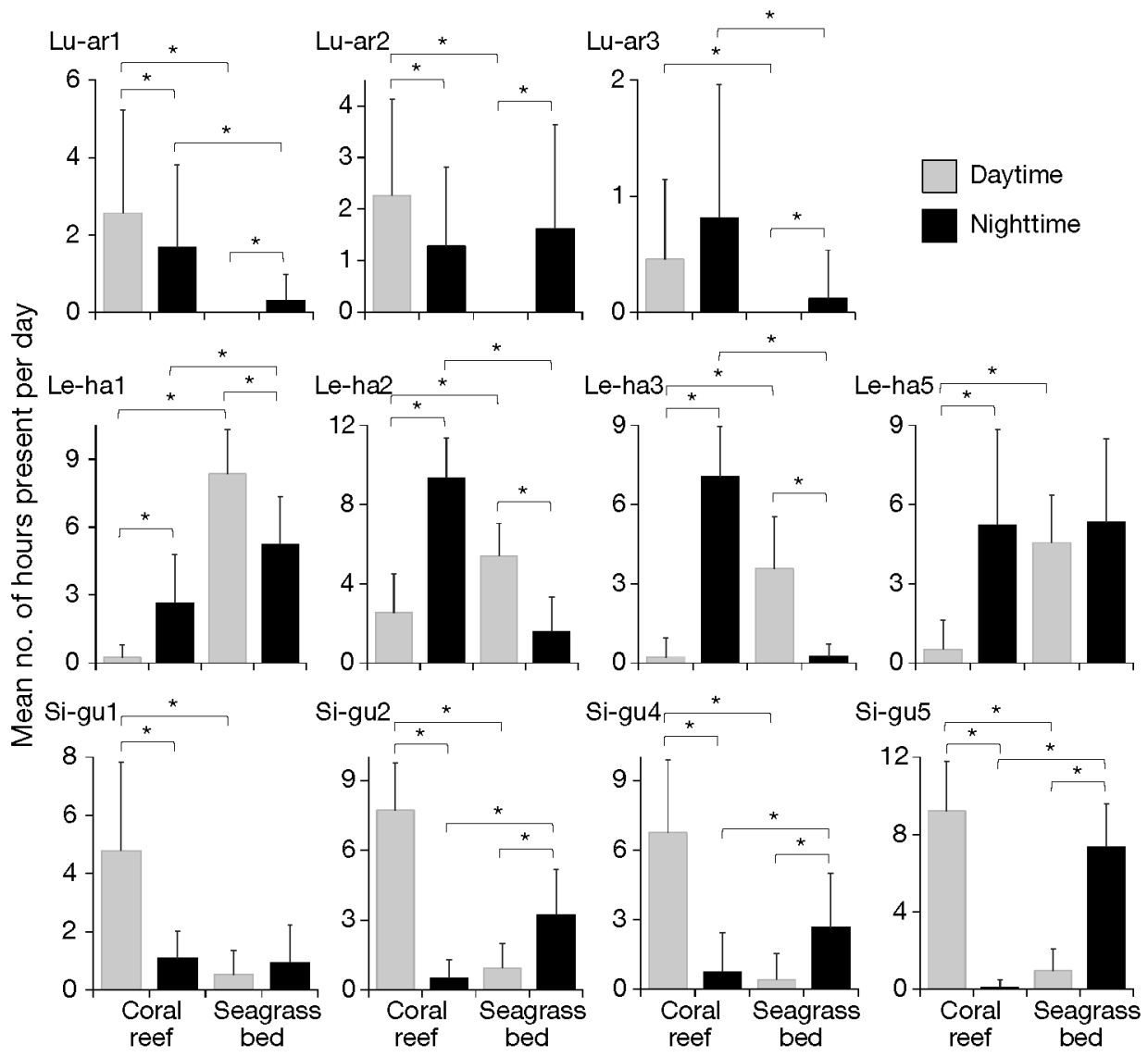

they showed the opposite pattern in the seagrass bed (Wilcoxon signed-rank test, $\mathrm{p}<0.05$ for Le-ha1 to 3 but $\mathrm{p}>0.05$ for Le-ha5) (Fig. 5). All 4 L. harak individuals occurred more in the seagrass bed than on the coral reef during the day (Wilcoxon signed-rank test, $\mathrm{p}<0.05)$, but no clear trend was observed during night. Conversely, all S. guttatus individuals occurred on the reef more during the day than during the night (Wilcoxon signed-rank test, $\mathrm{p}<0.05$ ) and vice-versa in the seagrass bed (Wilcoxon signed-rank test, $\mathrm{p}<0.05$ for Si-gu2, 4 and 5 but $\mathrm{p}>0.05$ for Sigu1) (Fig. 5). All 4 S. guttatus individuals occurred more on the reef than in the seagrass bed during the day (Wilcoxon signed-rank test, $\mathrm{p}<0.05$ ), while they showed the opposite pattern during the night (Wilcoxon signed-rank test, $\mathrm{p}<0.05$ for Si-gu2, 4 and 5 but $\mathrm{p}>0.05$ for Si-gu1).

\section{Occurrence patterns inside and outside the MPA}

Fishes were often detected inside the MPA (95.4\% of total detections) despite some movements outside (Fig. 2). More than $75 \%$ of the detections for all tracked fishes, except Lu-mo5 (38.5\%) and Le-ob1 $(22.3 \%)$, were recorded inside the MPA (Fig. 3). One or more movements between the inside and outside of the MPA were observed for 22 individuals $(78.6 \%$ of tracked fishes) among the 6 species. Eleven individuals moved, and 8 of these shuttled, between inside and outside the MPA more than once per day on average (Fig. 4b).

\section{Fish visual census}

All 6 species were observed in FVCs. Only Lethrinus harak was recorded outside the MPA

Fig. 5. Mean number of hours present per day $(+\mathrm{SD})$ in the coral reef and seagrass bed during the daytime and nighttime for the 11 tracked fishes recorded in both habitats. Refer to Table 1 for definitions of fish ID shown in the upper left of each figure. ${ }^{*}$ Significant difference tested at $\alpha=0.05$ using the Wilcoxon signed-rank test 
(Table 2). There were significantly more Lutjanus argentimaculatus on the coral reef inside than outside the MPA (Wilcoxon rank sum test, p < 0.05). Lethrinus harak and L. obsoletus were observed in the seagrass bed inside the MPA. Significantly more L. harak individuals were observed inside than outside the MPA (Wilcoxon rank sum test, $\mathrm{p}<0.05$ ).

Inside the MPA, the densities of Lutjanus argentimaculatus, L. monostigma, Lethrinus atkinsoni, and $S$. guttatus were higher in the coral reef than in the seagrass bed. The other 2 species showed the opposite pattern of distribution. However, for all of the species, the differences in density between the coral reef and seagrass bed were not significant (Wilcoxon rank sum test, $\mathrm{p}>0.05$ ) (Table 2).

\section{DISCUSSION}

When designing MPAs, there is an increasing awareness of the importance of habitat links between coral reefs and surrounding coastal ecosystems because some commercially important species use seagrass beds and mangrove areas as nursery grounds (see review by Nagelkerken 2009). In particular, conserving seagrass beds and mangrove areas is thought to lead to better fishery resources management, because the presence or absence of these habitats affects fish biomass and species richness on adjacent coral reefs (e.g. Nagelkerken et al. 2002, Mumby et al. 2004, Dorenbosch et al. 2005, Olds et al. 2012). In our previous study at this site, we found that many juveniles of several commercially important fish species use the seagrass and mangrove habitats as nursery grounds (Honda et al. 2013). In the present study, habitat connectivity was demonstrated by routine movements between the coral reef and the seagrass bed by similar-sized individuals of Lutjanus argentimaculatus (37.1 to $40.9 \mathrm{~cm}$ FL), Lethrinus harak (21.8 to $25.9 \mathrm{~cm}$ FL), and Siganus guttatus (23.2 to $25.0 \mathrm{~cm} \mathrm{FL).}$

The telemetry and FVC data showed similar trends in the daytime occurrence patterns in the coral and seagrass habitats. All tracked Lethrinus harak, a representative fish moving between habitats, occurred more frequently in the seagrass bed than on the coral reef during the day. Foraging behavior of $L$. harak in seagrass during the day has been observed at Okinawa, Japan (Nanami \& Yamada 2009) and also at our study site (K. Honda pers. obs.). Therefore, the observed movements toward the seagrass bed may be assumed to be for foraging. Among the 6 tracked L. harak, 5 (Le-ha6 was detected only in seagrass) were detected in the coral and seagrass habitats at night. They probably utilized both habitats as a resting place, because sleeping $L$. harak were occasionally observed under corals or near the bottom of the seagrass bed (K. Honda pers. obs.). The remaining 2 species showed somewhat similar diel habitat-use patterns. Although Lutjanus argentimaculatus and $S$. guttatus were mainly detected on the coral reef during the day by both telemetry and FVC, some individuals were detected in the seagrass bed at night by telemetry. Haemulid and lutjanid fishes in the Caribbean Sea exhibit diel foraging movements from coral reefs to seagrass beds and mangrove areas at night (Ogden \& Ehrlich 1977, Krumme 2009). Thus, L. argentimaculatus likely entered the seagrass bed (and/or the mangrove area) to forage at night. Although siganids are generally diurnal, $S$. guttatus becomes more active at night (Woodland 2001). Considering that a closely related species, $S$. lineatus, actively forages at night (Fox et al. 2009, Fox \& Bellwood 2011), the high detection frequency of $S$. guttatus at night probably reflected foraging activity.

The low sample number in the present study (some individuals were tracked for less than $1 \mathrm{wk}$ ) limits the strength of inferences we can draw from our results. However, a size-dependent habitat-use pattern was observed. Smaller fishes of Lutjanus monostigma (22.4 cm FL) and L. argentimaculatus (22.6 cm FL) 
occurred more frequently in the seagrass bed than did larger fishes $(\geq 27.7$ and $\geq 37.1 \mathrm{~cm} \mathrm{FL}$, respectively). Juveniles of these 2 species are known to inhabit mangrove areas (Shibuno et al. 2008, Yamada 2010, Honda et al. 2013). Therefore, the occurrence of smaller fishes in the seagrass bed may have resulted from their dependence on the mangrove area adjacent to the seagrass bed. The timing of the ontogenetic habitat shift from the mangrove and/or seagrass habitats to coral reefs is related to a reduced predation risk and a change in food items associated with growth (Grol et al. 2011, Nakamura et al. 2012). Huijbers et al. (2015) reported that only larger (19.8 \pm $3.9 \mathrm{~cm}$ FL) immature Lutjanus apodus in the Caribbean Sea moved from the nursery bay to coral reefs, which are the habitat for adult-sized fish ( $>25 \mathrm{~cm}$ FL). They concluded that these movements were likely related to ontogenetic habitat expansion. In further research, tracking the behaviors of intermediatesized fishes $(15$ to $25 \mathrm{~cm}$ ) will be useful to reveal the habitat dependence of the 2 species during the transitional phase of the ontogenetic habitat shift.

Fish detections for most target species were recorded inside the MPA. The FVC results supported this, and showed that for some species, the fish densities were significantly higher inside than outside the MPA. The telemetry results showed that more than one-third of individuals moved between the inside and outside of the MPA more than once per day on average. This result indicates that their full home ranges were not covered by the MPA. Furthermore, their movements may have been underestimated because the entire study area was not fully covered by the receivers. Taylor \& Mills (2013) used passive acoustic telemetry to track 12 Lethrinus harak and 6 L. obsoletus in an MPA mainly consisting of corals at Guam Island. Their results showed that the core home ranges $(95 \%$ kernel utilization distributions, Worton 1989) of these L. harak and L. obsoletus individuals ranged from 0.0026 to $0.082 \mathrm{~km}^{2}$ and from 0.004 to $0.022 \mathrm{~km}^{2}$, respectively. Thus, it is possible that the core home ranges of the tracked L. harak and L. obsoletus in this study were as small as those determined by Taylor \& Mills (2013). However, multiple factors should be considered when deciding the size of an MPA. Covering the full home range of many species by an MPA is unrealistic because of the size of the area required. Thus, including core areas of home ranges within an MPA would be an encouraging first step. Although the MPA at the study site covered the core home ranges of many fishes, local fisheries have been operating routinely along the MPA boundary, a fishery behavior known as 'fishing in line' (Roberts et al. 2001, Kellner et al. 2007). Considering that some fishes frequently moved across the MPA boundaries, the setting of a buffer zone outside the MPA, which would need partial amendment of the local fishery regulations, would protect the fish populations near the study site from high fishing pressure.

In this study, the core home ranges and diel habitat-use patterns of many fishes were identified by telemetry, and some findings were supported by the FVC. Understanding the core ranges of commercially important species using a visual transect survey is one of the most effective, low cost, and easy ways to determine the size of an MPA (e.g. Zeller et al. 2003, Kamukuru et al. 2004). Meanwhile, detailed diel habitat-use patterns and wider home ranges of commercially important species occurring in the target MPA can be determined by telemetry (e.g. Currey et al. 2014, Hussey et al. 2015). The effectiveness of MPAs will be enhanced by including recommended habitats (e.g. seagrass beds) and/or setting buffer zones based on the complementary information obtained by the concurrent use of both methods.

Acknowledgements. We thank the local government unit and fisherfolk of Barangay Tubajon, Laguindingan, particularly D. M. Gonzaga and J. Magdugo, for their collaborative efforts during the fieldwork. We are also grateful to $\mathrm{K}$. Nadaoka and E. Tsukamoto of the Tokyo Institute of Technology, M. D. Fortes of the University of the Philippines-Diliman, Y. Hamamitsu and Y. Nagahama of the Japan International Cooperation Agency, and V. E. Leopardas of Hokkaido University for their cooperation and assistance, and to the Mindanao State University at Naawan for the laboratory and technical support. This study was supported by the Japan Science and Technology Agency/Japan International Cooperation Agency Science and Technology Research Partnership for Sustainable Development, as part of the Integrated Coastal Ecosystem Conservation and Adaptive Management under Local and Global Environmental Impacts in the Philippines (CECAM) project.

\section{LITERATURE CITED}

Alós J, March D, Palmer M, Grau A, Morales-Nin B (2011) Spatial and temporal patterns in Serranus cabrilla habitat use in the NW Mediterranean by acoustic telemetry. Mar Ecol Prog Ser 427:173-186

> Carpenter KE, Springer VG (2005) The center of the center of marine shore fish biodiversity: the Philippine Islands. Environ Biol Fishes 72:467-480

Chateau O, Wantiez L (2009) Movement patterns of four coral reef fish species in a fragmented habitat in New Caledonia: implications for the design of marine protected area networks. ICES J Mar Sci 66:50-55

Christie P, Pollnac RB, Oracion EG, Sabonsolin A, Diaz R, Pietri D (2009) Back to basics: An empirical study demonstrating the importance of local-level dynamics for the success of tropical marine ecosystem-based management. Coast Manage 37:349-373

Collins AB, Heupel MR, Motta PJ (2007) Residence and 
movement patterns of cownose rays Rhinoptera bonasus within a south-west Florida estuary. J Fish Biol 71: $1159-1178$

Currey LM, Heupel MR, Simpfendorfer CA, Williams AJ (2014) Sedentary or mobile? Variability in space and depth use of an exploited coral reef fish. Mar Biol 161: 2155-2166

> Dorenbosch M, Grol MGG, Christianen MJA, Nagelkerken I, van der Velde G (2005) Indo-Pacific seagrass beds and mangroves contribute to fish density and diversity on adjacent coral reefs. Mar Ecol Prog Ser 302:63-76

Edgar GJ, Stuart-Smith RD, Willis TJ, Kininmonth S and others (2014) Global conservation outcomes depend on marine protected areas with five key features. Nature 506: 216-220

Farmer NA, Ault JS, Smith SG, Franklin EC (2013) Methods for assessment of short-term coral reef fish movements within an acoustic array. Mov Ecol 1:7

Fox RJ, Bellwood DR (2011) Unconstrained by the clock? Plasticity of diel activity rhythm in a tropical reef fish, Siganus lineatus. Funct Ecol 25:1096-1105

> Fox RJ, Sunderland TL, Hoey AS, Bellwood DR (2009) Estimating ecosystem function: contrasting roles of closely related herbivorous rabbitfishes (Siganidae) on coral reefs. Mar Ecol Prog Ser 385:261-269

Froese R, Pauly D (eds) (2015) FishBase. www.fishbase.org (accessed 26 May 2015)

> Grober-Dunsmore R, Frazer TK, Lindgerg WJ, Beets J (2007) Reef fish and habitat relationships in a Caribbean seascape: the importance of reef context. Coral Reefs 26: 201-216

> Grol MGG, Nagelkerken I, Rypel AL, Layman CA (2011) Simple ecological trade-offs give rise to emergent crossecosystem distributions of a coral reef fish. Oecologia 165:79-88

> Grüss A, Kaplan DM, Guénette S, Roberts CM, Botsford LW (2011) Consequences of adult and juvenile movement for marine protected areas. Biol Conserv 144:692-702

Halpern BS (2003) The impact of marine reserves: Do reserves work and does reserve size matter? Ecol Appl 13:117-137

Halpern BS, Warner RR (2003) Matching marine reserve design to reserve objectives. Proc R Soc B 270:1871-1878

Honda K, Nakamura Y, Nakaoka M, Uy WH, Fortes MD (2013) Habitat use by fishes in coral reefs, seagrass beds and mangrove habitats in the Philippines. PLoS ONE 8: e65735

> Huijbers CM, Nagelkerken I, Layman CA (2015) Fish movement from nursery bays to coral reefs: a matter of size? Hydrobiologia 750:89-101

> Hussey NE, Kessel ST, Aarestrup K, Cooke SJ and others (2015) Aquatic animal telemetry: a panoramic window into the underwater world. Science 348:1255642

Kamukuru AT, Mgaya YD, Öhman MC (2004) Evaluating a marine protected area in a developing country: Mafia Island Marine Park, Tanzania. Ocean Coast Manage 47: 321-337

Kellner JB, Tetreault I, Gaines SD, Nisbet RM (2007) Fishing the line near marine reserves in single and multispecies fisheries. Ecol Appl 17:1039-1054

> Kessel ST, Cooke SJ, Heupel MR, Hussey NE, Simpfendorfer CA, Vagle S, Fisk AT (2014) A review of detection range testing in aquatic passive acoustic telemetry studies. Rev Fish Biol Fish 24:199-218

Koeck B, Alós J, Caro A, Neveu R, Crec'hriou R, Saragoni G,
Lenfant P (2013) Contrasting fish behavior in artificial seascapes with implications for resources conservation. PLoS ONE 8:e69303

Krumme U (2009) Diel and tidal movements by fish and decapods linking tropical coastal ecosystems. In: Nagelkerken I (ed) Ecological connectivity among tropical coastal ecosystems. Springer Science and Business Media, Dordrecht, p 271-324

Luo J, Serafy JE, Sponaugle S, Teare PB, Kieckbusch D (2009) Movement of gray snapper Lutjanus griseus among subtropical seagrass, mangrove, and coral reef habitats. Mar Ecol Prog Ser 380:255-269

MacNeil M, Graham NAJ, Conroy MJ, Fonnesbeck CJ and others (2008) Detection heterogeneity in underwater visual-census data. J Fish Biol 73:1748-1763

Matley J, Heupel MR, Simpfendorfer CA (2015) Depth and space use of leopard coralgrouper Plectropomus leopardus using passive acoustic tracking. Mar Ecol Prog Ser 521:201-216

> Meyer CG, Papastamatiou YP, Timothy CB (2010) Differential movement patterns and site fidelity among trophic groups of reef fishes in a Hawaiian marine protected area. Mar Biol 157:1499-1511

Mora C, Andréfouët S, Costello MJ, Kranenburg C and others (2006) Coral reefs and the global network of marine protected areas. Science 312:1750-1751

- Mora C, Aburto-Oropeza O, Bocos AA, Ayotte PM and others (2011) Global human footprint on the linkage between biodiversity and ecosystem functioning in reef fishes. PLoS Biol 9:e1000606

Morrissey D (2015) Sunrise, sunset, moonrise and moonset times. www.sunrisesunsetmap.com (accessed 29 May 2015)

MPA Support Network (2014) Philippine MPA database. www.mpa.msi.upd.edu.ph (assessed 18 June 2015)

> Mumby PJ, Edwards AJ, Arias-Gonzalez JE, Lindeman KC and others (2004) Mangroves enhance the biomass of coral reef fish communities in the Caribbean. Nature 427:533-536

Nagelkerken I (ed) (2009) Evaluation of nursery function of mangroves and seagrass beds for tropical decapods and reef fishes: patterns and underlying mechanisms. In: Ecological connectivity among tropical coastal ecosystems. Springer Science and Business Media, Dordrecht, p 357-399

> Nagelkerken I, van der Velde G, Gorissen MW, Meijer GJ, Van't Hof T, den Hartog C (2000a) Importance of mangroves, seagrass beds and the shallow coral reef as a nursery for important coral reef fishes, using a visual census technique. Estuar Coast Shelf Sci 51:31-44

> Nagelkerken I, Dorenbosch M, Verberk WCEP, Cocheret de la Morinière E, van der Velde G (2000b) Day-night shifts of fishes between shallow-water biotopes of a Caribbean bay, with emphasis on the nocturnal feeding of Haemulidae and Lutjanidae. Mar Ecol Prog Ser 194:55-64

- Nagelkerken I, Roberts CM, van der Velde G, Dorenbosch M, van Riel MC, Cocheret de la Morinière E, Niehuis PH (2002) How important are mangroves and seagrass beds for coral-reef fish? The nursery hypothesis tested on an island scale. Mar Ecol Prog Ser 244:299-305

Nagelkerken I, Sheaves M, Baker R, Connolly RM (2013) The seascape nursery: a novel spatial approach to identify and manage nurseries for coastal marine fauna. Fish Fish 16:362-371

Nakamura Y, Hirota K, Shibuno T, Watanabe Y (2012) Variability in nursery function of tropical seagrass beds 
during fish ontogeny: timing of ontogenetic habitat shift. Mar Biol 159:1305-1315

- Nanami A, Yamada H (2009) Site fidelity, size, and spatial arrangement of daytime home range of thumbprint emperor Lethrinus harak (Lethrinidae). Fish Sci 75: 1109-1116

Newton K, Côté IM, Pilling GM, Jennings S, Dulvy NK (2007) Current and future sustainability of island coral reef fisheries. Curr Biol 17:655-658

> Ogden JC, Ehrlich PR (1977) The behavior of heterotypic resting schools of juvenile grunts (Pomadasyidae). Mar Biol 42:273-280

> Olds AD, Connolly RM, Pitt KA, Maxwell PS (2012) Habitat connectivity improves reserve performance. Conserv Lett 5:56-63

Olds AD, Albert S, Maxwell PS, Pitt KA, Connolly RM (2013) Mangrove-reef connectivity promotes the effectiveness of marine reserves across the western Pacific. Glob Ecol Biogeogr 22:1040-1049

Palumbi SR (2004) Marine reserves and ocean neighborhoods: the spatial scale of marine populations and their management. Annu Rev Environ Resour 29:31-68

> Payne NL, Gillanders BM, Webber DM, Semmens JM (2010) Interpreting diel activity patterns from acoustic telemetry: the need for controls. Mar Ecol Prog Ser 419:295-301

Pittman SJ, Monaco ME, Friedlander AM, Legare B and others (2014) Fish with chips: tracking reef fish movements to evaluate size and connectivity of Caribbean marine protected areas. PLoS ONE 9:e96028

Planes S, Jones GP, Thorrold SR (2009) Larval dispersal connects fish populations in a network of marine protected areas. Proc Natl Acad Sci USA 106:5693-5697

> Primavera JH (1995) Mangroves and brackish water pond culture in the Philippines. Hydrobiologia 295:303-309

R Core Team (2015) R: A language and environment for statistical computing. $\mathrm{R}$ Foundation for Statistical Computing, Vienna

Roberts CM, Bohnsack JA, Gell F, Hawkins JP, Goodridge R (2001) Effects of marine reserves on adjacent fisheries. Science 294:1920-1923

Russ GR (2002) Yet another review of marine reserves as reef fishery management tools. In: Sale PF (ed) Coral reef fishes: dynamics and diversity in a complex ecosystem. Academic Press, San Diego, p 421-443

Russ GR, Alcala AC (1996) Do marine reserves export adult fish biomass? Evidence from Apo Island, central Philippines. Mar Ecol Prog Ser 132:1-9

Russ GR, Alcala AC (2003) Marine reserves: rates and patterns of recovery and decline of predatory fish, 1983-2000. Ecol Appl 13:1553-1565

Sale PF, Cowen RK, Danilowicz BS, Jones GP and others (2005) Critical science gaps impede use of no-take fishery reserves. Trends Ecol Evol 20:74-80

Shanks AL, Grantham BA, Carr MH (2003) Propagule dispersal distance and the size and spacing of marine reserves. Ecol Appl 13:159-169

Shibuno T, Nakamura Y, Horinouchi M, Sano M (2008) Habitat use patterns of fishes across the mangroveseagrass-coral reef seascape at Ishigaki Island, southern Japan. Ichthyol Res 55:218-237

- Simpfendorfer CA, Heupel MR, Collins AB (2008) Variation in the performance of acoustic receivers and its implications for positioning algorithms in a riverine setting. Can J Fish Aquat Sci 65:482-492

Spalding MD, Ravilious C, Green EP (2001) World atlas of coral reefs. University of California Press, Berkeley, CA Spalding M, Wood L, Fitzgerald C, Gjerde KM (2010) The $10 \%$ target: where do we stand? In: Toropova C, Meliane I, Laffoley D, Matthews E, Spalding M (eds) Global ocean protection: present status and future possibilities. Agence des Aires Marines Protégées, Brest, France; IUCN WCPA, Gland, Switzerland, Washington, DC and New York, USA; UNEP-WCMC, Cambridge, UK; TNC, Arlington, USA; UNU, Tokyo, Japan; WCS, New York, p 25-40

Taylor BM, Mills JS (2013) Movement and spawning migration patterns suggest small marine reserves can offer adequate protection for exploited emperorfishes. Coral Reefs 32:1077-1087

> Tobey J, Torell E (2006) Coastal poverty and MPA management in mainland Tanzania and Zanzibar. Ocean Coast Manage 49:834-854

- Unsworth RKF, Cullen LC (2010) Recognising the necessity for Indo-Pacific seagrass conservation. Conserv Lett 3: $63-73$

Unsworth RKF, Bell JJ, Smith DJ (2007) Tidal fish connectivity of reef and sea grass habitats in the Indo-Pacific. J Mar Biol Assoc UK 87:1287-1296

Unsworth RKF, Salinas De León P, Garrard SL, Jompa J, Smith DJ, Bell JJ (2008) High connectivity of Indo-Pacific seagrass fish assemblages with mangrove and coral reef habitats. Mar Ecol Prog Ser 353:213-224

> Unsworth RKF, Garrard SL, Salinas De León P, Cullen LC, Smith DJ, Sloman KA, Bell JJ (2009) Structuring of IndoPacific fish assemblages along the mangrove-seagrass continuum. Aquat Biol 5:85-95

> Weeks R, Russ GR, Alcala AC, White AT (2010) Effectiveness of marine protected areas in the Philippines for biodiversity conservation. Conserv Biol 24:531-540

Welsh JQ, Bellwood DR (2012) Spatial ecology of the steephead parrotfish (Chlorurus microrhinos): an evaluation using acoustic telemetry. Coral Reefs 31:55-65

> Welsh JQ, Fox RJ, Webber DM, Bellwood DR (2012) Performance of remote acoustic receivers within a coral reef habitat: implications for array design. Coral Reefs 31: 693-702

White AT, Vogt HP, Arin T (2000) Philippine coral reefs under threat: the economic losses caused by reef destruction. Mar Pollut Bull 40:598-605

White AT, Meneses ABT, Ovenden M, Tesch S (2006) Sustaining marine protected areas through continued monitoring and evaluation: the MPA report guide and management rating system. Proc 10th Int Coral Reef Symp, Okinawa, Japan, June 28-July 2, 2004, p 1466-1470

Woodland DJ (2001) Siganidae. In: Carpenter KE, Niem VH (eds) FAO species identification guide for fishery purposes. The living marine resources of the Western Central Pacific, Vol 6. Bony fishes, part 4 (Labridae to Latimeriidae), estuarine crocodiles, sea turtles, sea snakes and marine mammals. FAO, Rome, p 3627-3650

> Worton BJ (1989) Kernel methods for estimating the utilization distribution in home-range studies. Ecology 70 : $164-168$

Yamada H (2010) Age and growth during immature stages of the mangrove red snapper Lutjanus argentimaculatus in waters around Ishigaki Island, southern Japan. Fish Sci 76:445-450

Zeller D, Stoute SL, Russ GR (2003) Movements of reef fishes across marine reserve boundaries: effects of manipulating a density gradient. Mar Ecol Prog Ser 254:269-280 